\title{
EDUCATIONAL ROLE AND SIGNIFICANCE OF HOMEWORK IN BEGINNER MATHEMATICS TEACHING
}

\section{Sead Rešić1 Amra Borogovac}

Department of Mathematics of Natural Sciences, University of Tuzla Elementary school „Miladije“, Tuzla

Received: 20.03.2014. Accepted: 21.04.2014.

\author{
Original scientific paper
}

UDC: $371.322 .1: 51$

\begin{abstract}
In this research, the attitudes of students, teachers and parents regarding the role and significance of homework in Mathematics beginner teaching, were analyzed. Through a sample of 345 examinees (21 teacher, 219 students and 105 parents), attitudes and individual opinions regarding the given issued were examined. The research employed descriptive method, theoretical analysis method and survey method, while the research techniques consisted of questionnaire and statistical data analysis. Results of the research are demonstrated in graphical and tabular manner, including explanation and discussion. In the conclusion, attitudes of students, teachers and parents regarding the role and significance of homework in Mathematics beginner teaching are stated and explained.
\end{abstract}

Key words: Mathematics, teaching, teacher, student, parent

\section{INTRODUCTION}

Throughout the history of teaching, attitude towards students' homework has not always been equable, and that is the case nowadays as well. Besides lesson revision, homework encompasses practicing in order to acquire reading, writing, and calculating skills.

Apprehensions vary regarding the necessity of writing homework, manners of examining it and whether it should be taken into account when finalizing grades, etc. Today, the dilemma revolves around questions such as what the child needs, what is the necessary scope of knowledge, and how much of what exactly is to be demanded from a child to do individually at home, in terms of feedback (Tomić \& Osmić, 2006). This vagueness leads to variations in the work of many teachers, and the questions are posed: 'What is homework', 'How to assign homework', 'What to give for homework', 'How much of it should be assigned' and 'Is homework really necessary'? Homework is students' activity, which stems from everyday obligations toward work at school, but is conducted outside schoolwork. It is also possible to provide answer to the question 'How to assign homework?' Firstly, most tasks prepared for students' individual work should be textual with information from their immediate surroundings. Teacher's obligation is to analyze every task with students and provide directions for work, which ensures success in the process of teaching.

\footnotetext{
${ }^{1}$ Correspondence to:

Šabana Zahirovića 10, Tuzla, B\&H

Phone: +38761101230

E-mail: sresic@hotmail.com
}

Sead Rešić, Department of Mathematics, Faculty of Natural Sciences, University of Tuzla 
The question 'What to give for homework?' is not difficult to answer, if the teacher bears in mind that everything that was the subject of discussion in previous classes should be the subject of individual work as well, it is best to assign tasks that encompass more than one teaching unit (Bunđur \& Potkonjak, 2002).

The answer to the question 'How much homework should be assigned?' is that it depends on the grade, content, structure and difficulty of the subject matter. Homework is a significant factor in developing students' individuality (including transcribing) (Prodanović, 1967).

The higher the level of interest for Mathematics teacher is able to entice, the more certain they can be that child will individually arrive to the result. This is mutually a great success! Otherwise, the child becomes overburdened with various demands from the teacher or even develops resistance to school, homework and generally, responsibility towards work.

\section{THEORETICAL ELABORATION OF THE SUB- JECT}

\section{Mathematics beginner teaching}

Mathematics teaching in the first five grades of elementary school in Bosnia and Herzegovina is labeled as beginner, while the scientific discipline, which researches education within this teaching, is called methodology of beginner Mathematics teaching. Each type of methodology, including methodology of beginner Mathematics teaching, has its subject of research, and in this case it is Mathematical education in the first five grades of elementary school (Markovac, 1992).

The aim of Mathematics teaching should be to familiarize students with all aspects of Mathematical activity, with adjustments to students' mathematical abilities and basic knowledge (Kurnik, 2009).

\section{Brief history and significance of homework}

Homework has been, since ancient times, considered as part of schoolwork, but still there were opinions that homework is unnecessary and even detrimental for students. The point of this stream of thought was that the entire process of acquiring and establishing knowledge must take place during class, and every other burden is detrimental for students.

According to Džaferović (1972), the forms of homework are practising, problem solving, learning by heart - all of which has roots in class teaching.

\section{Definition and classification of homework}

The aim of homework is revising, affirming, acquiring the subject matter, expanding and deepening knowledge, preparing for acquisition of new subject matter, training and forming skills and habits.

Homework is classified into three groups (Trnovac \& Đorđević, 1998):

- Oral (learning from textbooks, handbooks, learning lyrics, rules, unfamiliar words, etc.)

- Written (various written homework: practising, solving mathematical and other tasks, presentations, resports, essays, translations from a foreign language, etc.)

- Practical (observation, tests, experiments, various proof acquisition, charting, making models, graphs, tables, etc.)

The role and significance of homework in beginner Mathematics teaching

Students' homework represents one part of teaching work plan. It derives from class teaching itself and becomes included in it in different times during the teaching process and in various forms.

Students' homework has a multifaceted role. First and foremost, it represents individual work, helps students' independence in the process of acquiring knowledge, which also leads to necessary preparation for life outside school. Homework helps ascertain knowledge and practice habits, as well as application of acquired knowledge. Homework presents preparation for the next schoolwork and has a special upbringing task, which consists of developing the sense of responsibility toward tasks placed in front of the student: hard work, organization, etc.

Homework may have various aims: to practice and solidify acquired knowledge, skills and habits, to systematize and generalize knowledge, skills and habits, to prepare students for work in the next class, all of which has roots in class teaching. Homework may have different content. It can encompass solving numerical tasks, which have the aim to help practice a certain calculus operation, calculus technique; solving tasks in words, where students apply calculus knowledge, mathematical operations, practice deduction, etc.Rešić (2013) suggests that games can also be employed to help personal development, as well as to improve the player's (student's) self-confidence.

According to Ćetković \& Pinter (1998), Rešić (2013) claims: "The subject of Mathematics is such a serious subject matter, that it is very useful to seize every opportunity to make it at least a bit more fun". 
Accomplishing upbringing tasks in Mathematics teaching through games is the most suitable way of this part of education in lower grades of elementary school. The need for playing games is expressed in a human being throughout his/her entire life, and especially at this age.

\section{RESEARCH METHODOLOGY}

\section{Theoretical significance}

Theoretical significance of this research is to contribute to examining the issue of homework in beginner Mathematics teaching, as well as to point out both its positive and negative aspects. Shedding light on this issue theoretically should contribute to solving the problem.

\section{Practical significance}

Practical significance of this issue is in the hope that results and content of this research will help teachers, students and parents in solving the problem of homework, and point to the right way of finding adequate solution for overcoming unclear questions regarding homework.

\section{Social significance}

This research should emphasize advantages of homework in educating students, as well as focal points of his/her strong and weak knowledge and point out where students' need help.

\section{Aim of research}

Starting from the perceived and stated problem, the aim of this research is to explore, critically analyze, ascertain and interpret attitudes of teachers, parents and students regarding educational and upbringing role and significance of homework in beginner Mathematics teaching. The research will ascertain the level of connection between students' burden with homework and motivation for learning subject matter, as well as optimal exertion with homework for students; parents' involvement in completing homework, importance of homework for the teacher, and whether the teacher divides homework according to different levels of students' knowledge.

\section{Research tasks}

In this research, the following tasks served as starting points:

T1. Ascertain the level of connection between temporal exertion of students with homework on a weekly basis and exertion of students with homework determined by pedagogical norm;

T2. Determine the level of participation of parents in helping complete homework;

T3. Find out the level of connection between homework differentiation and students' motivation to complete homework;

T4. Ascertain the level of importance of homework for school subject teacher;

T5. Find out whether there is a difference in homework for students with different knowledge levels (excellent - satisfactory);

T6. Ascertain whether teachers regularly assign homework for their students.

\section{Main hypothesis}

Educational role and significance of homework in beginner Mathematics teaching has a positive effect on students' progress, claims an important place in the Mathematics learning and teaching process, and there is reciprocity between students' exertion with homework during the week with their exertion with homework determined by pedagogical norm.

Sub-hypotheses

H1: Students' exertion with homework during the week and their exertion with homework determined by pedagogical norm is reciprocal.

H2. Parents help students a lot with completing homework.

H3. Students are sufficiently motivated to complete homework.

H4.Teachers consider analysis and evaluation of homework important.

H5. Teachers divide homework tasks for students with different levels of knowledge, therefore there are significant differences in the volume of homework.

H6. Teachers regularly assign homework to their students.

\section{Sample}

The research was conducted in Elementary school "Miladije" in Tuzla, during October and November. The questionnaire encompassed a sample of 21 teachers and 219 students (65 students in 2nd grade, 82 students in 3rd grade and 72 students in 4 th grade), while 105 parents were interviewed by random choice.

The students sample was simply, randomly chosen. Basic characteristic of simple, random choice of sample is equal probability that all students will be satisfied with the homework they get from the teacher. 


\section{Research methods}

In this research, theoretical analysis the method was applied, as well as descriptive method and survey method, in order to gather information necessary to solve this problem.

Descriptive method and theoretical analysis method were useful for pointing out the most important theoretical observations and empirical contributions to studying educational role and significance of homework.

Theoretical analysis method generally employs deduction as logical-methodological procedure in pedagogical research.

\section{Research techniques}

In order to gather concrete data relevant for this research paper, the following research techniques were used: questionnaire and arranging gathered information and statistical data analysis

\section{Instruments}

Within the framework of research technique, there are adequate tools, i.e. research instruments, which serve to identify, gather and measure scientifically based facts (Banđur \& Potkonjak, 2002).

For this research, the following instruments were constructed and employed: Questionnaire for students, teachers and parents.

\section{Organization and research flow}

Research regarding educational role and significance of homework in beginner Mathematics teaching was conducted during academic year 2012/13 in parentteacher conferences from 12/12/2012 to $23 / 12 / 2012$ and in the meeting of Association for lower elementary teaching, held 26/12/2012. Parents completed questionnaires during parent-teacher conference on voluntary basis, and all the teachers completed them right away.

\section{ANALYSIS AND INTERPRETATION OF RE- SEARCH RESULTS}

Taking into consideration theoretical points of view and research performed by other authors, this research began with the supposition that student exertion during the week is reciprocal to student exertion during a time defined by pedagogical norms. It is assumed that students are motivated sufficiently to complete their homework and that teacher adequately evaluates and analyzes homework, so that the tasks can be adapted to current knowledge of students.

Answers to the question: "Do you motivate students daily to do complete homework?" can be seen in Table 1 (Figure 1).

Analysis of responses shows that as high as $48 \%$ of teachers rarely motivate students to complete their homework, which negates the third sub-hypothesis.

Table 1. Teachers' attitudes toward educational role and significance of homework in beginner Mathematics teaching

\begin{tabular}{lcc}
\hline $\begin{array}{c}\text { Teachers } \\
\text { responses }\end{array}$ & Do you motivate students daily to do complete homework? \\
& $\mathrm{f}$ & $\%$ \\
\hline ALWAYS & 10 & 33 \\
RARELY & 5 & 48 \\
SOMETIMES & 6 & 19 \\
\hline Total: & $\mathbf{2 1}$ & $\mathbf{1 0 0}$ \\
\hline
\end{tabular}

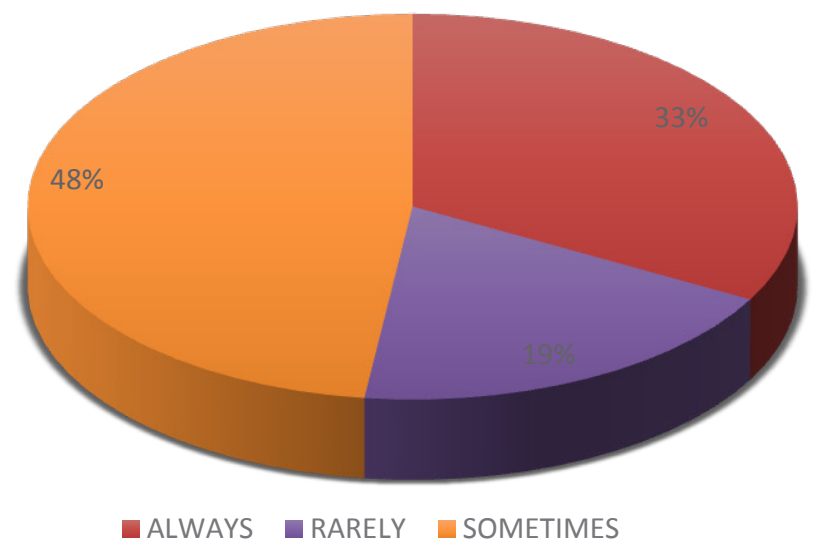


To the question: "When assigning homework to students, do you explain the tasks?", we Gathered the following answers:
Majority of $62 \%$ of teachers claim that they explain homework tasks, which confirms sub-hypothesis 4. (Table 2; Figure 2).

Table 2. Teachers'attitudes toward educational role and significance of homework in beginner Mathematics teaching

\begin{tabular}{lcc}
\hline & \multicolumn{3}{c}{$\begin{array}{c}\text { Survey question } \\
\text { Teachers' } \\
\text { responses }\end{array}$} & $\begin{array}{l}\text { When assigning homework to students, do you explain the } \\
\text { tasks? }\end{array}$ & $\mathrm{f}$ & $\%$ \\
\hline ALWAYS & 13 & 62 \\
SOMETIMES & 5 & 24 \\
NEVER & 3 & 14 \\
\hline Total: & $\mathbf{2 1}$ & $\mathbf{1 0 0}$ \\
\hline
\end{tabular}

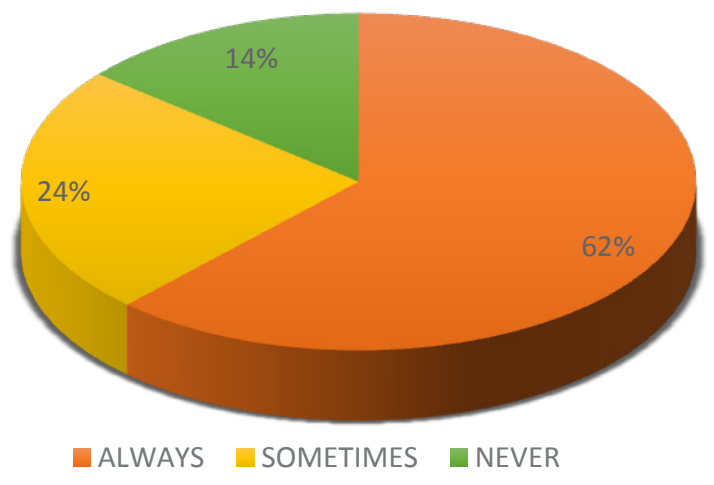

The survey question: "Do you use grades as motiva- Only $29 \%$ of teachers claim that they use grades as tion for students who regularly and correctly complete motivation, while 52\% do it sometimes and 19\% nevtheir homework?", yielded the following answers: er. (Table 3; Figure 3).

Table 3. Teachers'attitudes toward educational role and significance of homework in beginner Mathematics teaching

\begin{tabular}{|c|c|}
\hline \multirow{3}{*}{$\begin{array}{l}\text { Teachers' } \\
\text { responses }\end{array}$} & Survey question \\
\hline & $\begin{array}{l}\text { Do you use grades as motivation for students who } \\
\text { regularly and correctly complete their homework? }\end{array}$ \\
\hline & $\mathrm{f} \quad \%$ \\
\hline ALWAYS & 29 \\
\hline RARELY & 19 \\
\hline SOMETIMES & 11 \\
\hline Total: & 100 \\
\hline
\end{tabular}

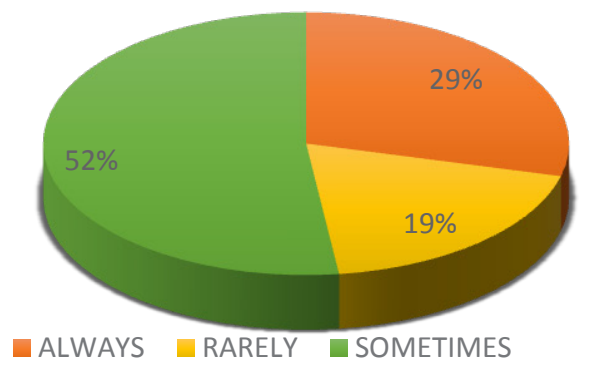


Survey question: "Is the number of tasks for homework relevant or irrelevant, that is, does a greater number of tasks mean more practicing or better mem- ory?", gave the following replies (Table 4; Figure 4). Hence, the number of tasks is irrelevant, but the type of tasks is relevant in learning Mathematics.

Table 4. Teachers' attitudes toward educational role and significance of homework in beginner Mathematics teaching

\section{Survey question}

\section{Teachers' responses}

Is the number of tasks for homework relevant or irrelevant, that is, does a greater number of tasks mean more practicing or better memory?
$\%$

a) the number of tasks is irrelevant, but the type of tasks is relevant in learning Mathematics

b) the number of tasks is relevant in learning Mathematics

c) type of tasks is not the most important factor in acquiring mathematical knowledge

Total:

\section{1}

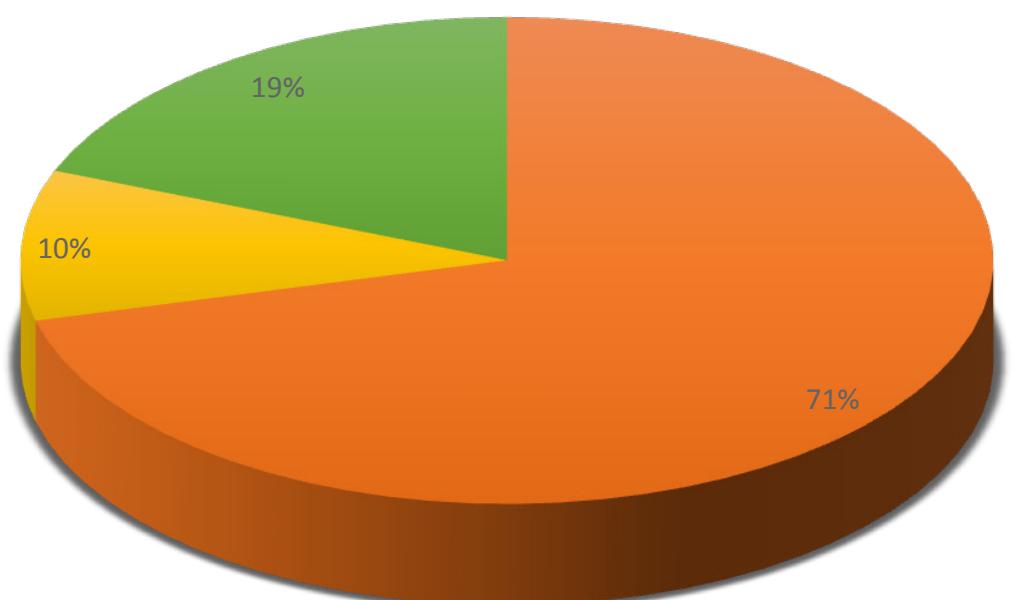

- The number of tasks is irrelevant, but the type of tasks is relevant in learning Mathematics - The number of tasks is relevant in learning Mathematics

-Type of tasks is not the most important factor in acquiring mathematical knowledge

STUDENTS' ATTITUDES TOWARD EDUCATIONAL ROLE AND SIGNIFICANCE OF HOMEWORK IN BEGINNER MATHEMATICS TEACHING

Since students are those who feel the real role and significance of homework the most, we examined their attitudes and opinions, while aware of limitations that are present. The sample included 219 students (65 students in 2nd grade, 82 students in 3rd grade and 72 students in 4th grade).

Based on gathered data, we reached the following results: IV grade -72 students in total

According to data in tables (II, III, IV grade), (in this paper IV grade is presented tabular), it can be seen that most students get homework every day, even on weekends, which is a great burden for them; that it takes them a long time to complete homework even though parents help them; that they are not particularly motivated to complete homework, which is not even explained to them properly; students also claim that teachers, even though they examine homework, they do not always pay attention to accuracy, and they do not give different tasks to weaker, average and excellent students; students claim to be burdened by the amount of homework related to other subjects. There are no significant differences between II, III and IV grade. 
Table 5. Students' attitudes toward educational role and significance of homework in beginner Mathematics teaching

\begin{tabular}{|c|c|c|c|c|c|c|}
\hline Survey question & YES & $\%$ & NO & $\%$ & SMT. & $\%$ \\
\hline $\begin{array}{l}\text { 1.Every day, when you have Mathematics class, do } \\
\text { you get homework? }\end{array}$ & 43 & 60 & 10 & 14 & 19 & 26 \\
\hline 2.Do you get tasks to complete during the weekend? & 36 & 50 & 19 & 26 & 17 & 24 \\
\hline 3.Does it take a long time to finish your homework? & 41 & 57 & 17 & 24 & 14 & 19 \\
\hline 4.Do your parents help you complete homework? & 39 & 54 & 8 & 11 & 25 & 35 \\
\hline $\begin{array}{l}\text { 5.Is your homework similar to tasks you do in } \\
\text { class? }\end{array}$ & 39 & 54 & 15 & 21 & 18 & 25 \\
\hline $\begin{array}{l}\text { 6.Does your teacher motivate you beforehand to do } \\
\text { your homework? }\end{array}$ & 19 & 26 & 26 & 36 & 27 & 38 \\
\hline $\begin{array}{l}\text { 7.Does your teacher explain homework while } \\
\text { assigning it? }\end{array}$ & 30 & 42 & 29 & 40 & 13 & 18 \\
\hline $\begin{array}{l}\text { 8.Does your teacher often examine your } \\
\text { homework? }\end{array}$ & 33 & 46 & 22 & 30 & 17 & 24 \\
\hline $\begin{array}{l}\text { 9.Does your teacher pay attention to accuracy of } \\
\text { your homework? }\end{array}$ & 34 & 47 & 30 & 42 & 8 & 11 \\
\hline $\begin{array}{l}\text { 10.Is there a difference in homework tasks for } \\
\text { weaker, average and excellent students? }\end{array}$ & 12 & 17 & 45 & 62 & 15 & 21 \\
\hline $\begin{array}{l}\text { 11.During one day, do you get homework from one } \\
\text { or more subjects? }\end{array}$ & 41 & 57 & 9 & 12 & 22 & 31 \\
\hline
\end{tabular}

PARENTS' ATTITUDES TOWARD EDUCATIONAL ROLE AND SIGNIFICANCE OF HOMEWORK IN BEGINNER MATHEMATICS TEACHING

Beginning with the assumption that parents help their children a lot in order to complete homework, as well as that parents believe that children are over-burdened with content and volume of homework, we arrived to certain attitudes and opinions.

In the same manner that we examine attitudes of teachers and students, we also examined attitudes of parents.
Namely, we wished to explore whether their attitudes are random or significant for this research, and whether valid conclusions can be drawn based on those attitudes.

To the question: "Do you believe that students are exerted by homework in relation to weekly number of classes?", we got the following answers:

Most parents claim that students are over-burdened with the amount of tasks they get for homework, as many as $64 \%$ believe this, so the first sub-hypothesis is negated. (Table 6; Figure 5).

Table 6. Parents' attitudes toward educational role and significance of homework in beginner Mathematics teaching

\section{Survey question}

Parents' replies

Do you believe that students are exerted by homework in relation to weekly number of classes?

\begin{tabular}{lcc} 
& $\mathrm{f}$ & $\%$ \\
\hline YES & 67 & 64 \\
NO & 13 & 12 \\
SOMETIMES & 25 & 25 \\
\hline Total: & $\mathbf{1 0 5}$ & $\mathbf{1 0 0}$ \\
\hline
\end{tabular}

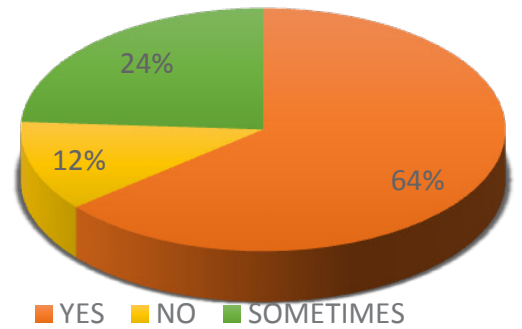


Survey question: "Have you noticed that teachers do not pay attention to accuracy of homework? " yielded the following information:

As many as $54 \%$ of parents claim that teachers do not pay enough attention to homework and its accuracy, which negates our fourth sub-hypothesis - that homework has a significant role and significance for the teacher (Table 7; Figure 6).

Table 7. Parents' attitudes toward educational role and significance of homework in beginner Mathematics teaching

\begin{tabular}{lcc}
\hline \multirow{2}{*}{ Parents' replies } & \multicolumn{2}{c}{ Survey question } \\
& $\begin{array}{c}\text { Have you noticed that teachers do not pay attention to } \\
\text { accuracy of homework? }\end{array}$ & $\%$ \\
\cline { 2 - 3 } YES & $\mathrm{f}$ & 54 \\
NO & 57 & 12 \\
SOMETIMES & 12 & 34 \\
\hline Total: & 36 & $\mathbf{1 0 0}$ \\
\hline
\end{tabular}

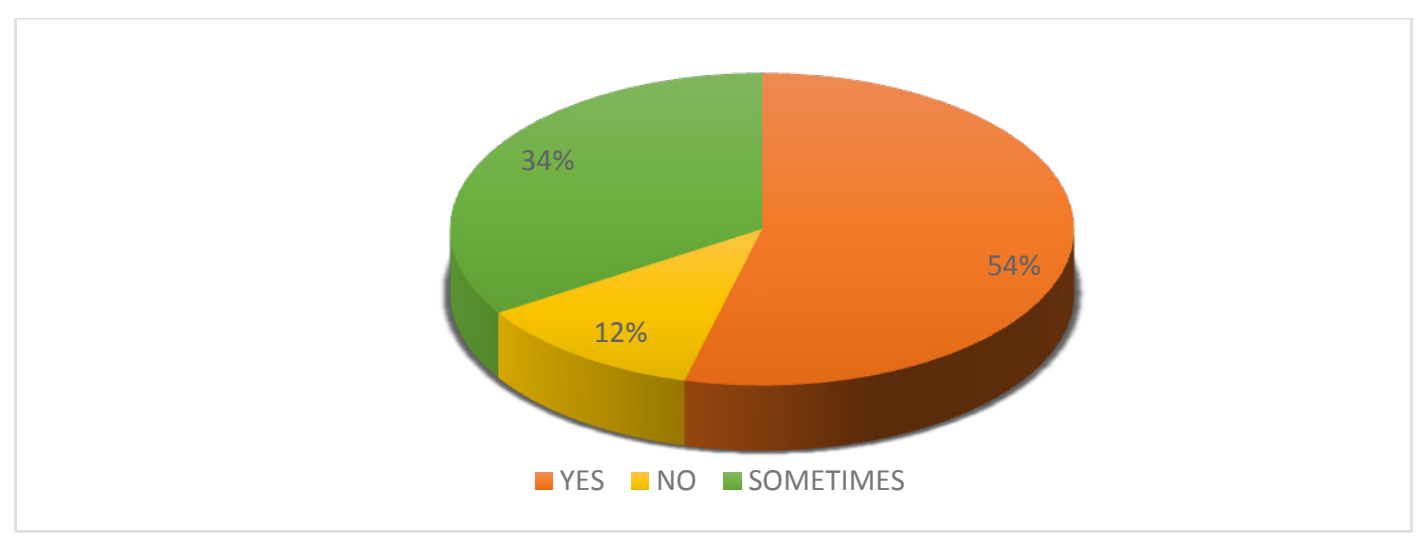

The question: "Do you believe that it would be cor- weaker, average and excellent students?", gave us the rect for teachers to assign different homework for following answers (Table 8; Figure 7):

Table 8. Parents' attitudes toward educational role and significance of homework in beginner Mathematics teaching

\section{Survey question}

Parents' replies

Do you believe that it would be correct for teachers to

\begin{tabular}{|c|c|c|}
\hline Parents' replies & $\begin{array}{r}\text { assign diff } \\
\text { excellent st } \\
\mathrm{f} \\
\end{array}$ & $\begin{array}{l}\text { eaker, average and } \\
\%\end{array}$ \\
\hline YES & 66 & 63 \\
\hline NO & 19 & 18 \\
\hline SOMETIMES & 20 & 19 \\
\hline Total: & 105 & 100 \\
\hline
\end{tabular}

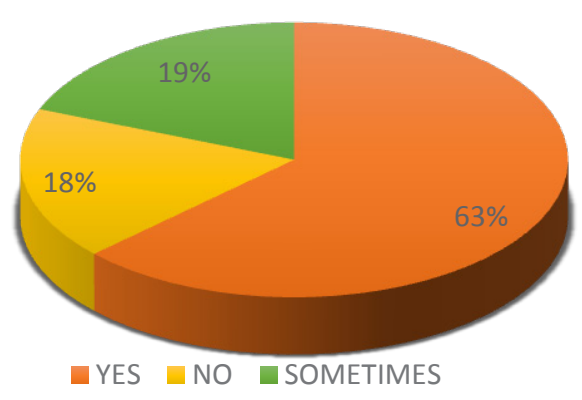




\section{CONCLUSION}

In beginner Mathematics teaching, homework significantly contributes to upbringing and educational process, develops the sense of responsibility in students, their independence, familiarizes them with daily activities schedule, contributes to development of mental abilities and helps fortifying students' knowledge. Based on research and upon analysis of gathered data, the following conclusions can be drawn:

- There are certain differences in volume, quality, and structure of homework in beginner Mathematics teaching

- Teachers still look upon homework in a reduced, narrow way, so that some of them believe that homework is necessary, while others do not

- Homework is evaluated in different manners

- Parents, who believe that homework should be assigned and that it is good and valuable for their children, attribute great significance to homework

It is difficult to elaborate on the demand against timeconsuming, exhausting homework until the real state of affairs is examined in practice. This problem exists, but many do not wish to admit it.

Much is needed, more is given, and too much is demanded. Homework, in the sense it is defined, with precisely pedagogically designed tasks, reasonable and optimal time consumption - YES. Homework which exhausts, degrades, psychologically burdens the child, limits the childs time - NO. This kind of homework should not exist, and the sooner it is rooted out, the better. Taking into consideration significance, upbringing and educational goals which should be achieved through homework, as well as certain elements brought out in this research, which significantly influenced fairly low quality of students' homework so far, it would be a duty for teachers, as well as students' parents, to put in more effort and take nec- essary steps in order to increase responsibility of all students for their obligations.

Therefore, even though teachers believe that homework helps develop responsibility and fortify knowledge, when said homework gains proportions of small encyclopedia, children quickly lose motivation and wonder if they are at all interested in what their task is. It would be much more efficient if parents, together with teachers, agree at school on more appropriate and quality homework. We believe that children in lower grades of elementary school should be given homework that takes a maximum of five minutes and is directly connected to subject matter elaborated on at school that day. As for the waste of time, both parents and teachers waste it, which means there is less time for quality revision or elaboration on new subject matter.

It is important to pint out the seriousness and interest of all parties in this subject, as well as the wish to take quality steps toward more quality teaching and more comfortable atmosphere at school and about it. We believe that with concrete activities, in accordance with acquired responses, we will make the first important step toward a more satisfied student and his/ her parent.

\section{REFERENCES}

Banđur, V. I Potkonjak, N. (2002). Istraživanje u školi. Serbia, Užice: Učiteljski fakultet

Markovac, J. (1992). Metodika početne nastave matematike. Croatia, Zagreb: Školska knjiga

Tomić,R. i Osmić, I. (2006). Didaktika. B\&H, Tuzla: Danfas

Džaferović, Dž. (1972). Pedagogija i didaktika. B\&H, Tuzla: Grafičar

Prodanović, T. (1967). Osnovi didaktike. Serbia, Belgrade: Zavod za udžbenike

Kurnik, Z. (2009). Znanstveni okviri nastave matematike. Croatia, Zagreb: Element-Zagreb

Rešić, S. (2013.). Matematika I- Metodika početne nastave. B\&H, Tuzla: Papir karton doo Tuzla 